\title{
Physics Based Analytical Modeling of Asymmetric Elevated Source Tunnel FET (AES-TFET) for Better Tunnel Junction Device (TJD) Performance
}

\section{Research Article}

Keywords:

Posted Date: March 24th, 2021

DOI: https://doi.org/10.21203/rs.3.rs-281800/v2

License: (c) (1) This work is licensed under a Creative Commons Attribution 4.0 International License.

Read Full License 


\section{Abstract}

The authors have requested that this preprint be withdrawn due to erroneous posting.

\section{Full Text}

The authors have withdrawn this preprint from Research Square. 